\title{
PEMBERIAN AIR REBUSAN DAUN JAMBU BIJI TERHADAP KADAR GLUKOSA DARAH PENDERITA DIABETES MELITUS
}

\author{
GIVING BOILED WATER JAMBU SEEDS TO BLOOD GLUCOSE LEVELS OF \\ DIABETES MELLITUS PATIENTS
}

\author{
Kartin Buheli, Ratnawati \\ Poltekkes Kemenkes Gorontalo \\ Kontak penulis: ratna.harzan@gmail.com
}

\begin{abstract}
ABSTRAK
Penelitian ini bertujuan untuk mengetahui pengaruh pemberian air rebusan daun jambu biji terhadap kadar glukosa darah pada penderita diabetes melitus di Puskesmas Kota Selatan Kota Gorontalo. Metode yang dipakai dalam penelitian ini yaitu metode Pra-Expreriment yang bersifat One group pre-test dan post-test design. Populasi dalam penelitian ini adalah semua penderita diabetes melitus di Puskesmas Kota Selatan Kota Gorontalo yang berjumlah 64 Penderita. Adapun ampel yang akan diambil oleh peneliti berjumlah 37 orang menggunakan teknik purposive sampling. Hasilnya, yaitu ada pengaruh yang sangat signifikan antara air rebusan daun jambu biji dan penurunan kadar glukosa darah pada penderita diabetes melitus di Wilayah Kerja Puskesmas Kota Selatan.
\end{abstract}

Kata Kunci: jambu biji: glukosa darah; diabetes melitus

\section{ABSTRACT}

This study aims to determine the effect of guava leaf boiled water on blood glucose levels in diabetes mellitus sufferers at the South City Health Center, Gorontalo City. The method used in this research is the pre-experiment method which is one group pre-test and post-test design. The population in this study were all 64 patients with diabetes mellitus in the South City Health Center, Gorontalo City. There were 37 samples taken by the researcher using purposive sampling technique. The result is that there is a very significant effect between boiled water of guava leaves and a decrease in blood glucose levels in people with diabetes mellitus in the working area of Puskesmas Kota Selatan.

Keywords: guava: blood glucose; diabetes mellitus 


\section{Pendahuluan}

Diabetes adalah penyakit kronis yang terjadi karena insulin yang dihasilkan pankreas tidak cukup (hormon yang mengatur gula darah atau glukosa), atau ketika insulin yang dihasilkan tubuh tidak dapat secara efektif digunakan. Diabetes adalah masalah kesehatan yang penting, menjadi salah satu dari empat penyakit tidak menular prioritas yang menjadi target tindak lanjut oleh para pemimpin dunia (Kementerian Kesehatan Republik Indonesia, 2020).

Diabetes melitus adalah suatu jenis penyakit yang disebabkan oleh terganggunya fungsi pankreas yang tidak mampu memproduksi hormon insulin sesuai kebutuhan metabolisme tubuh, sehingga kadar gula dalam darah mengalami peningkatan dan melebihi ambang batas normal (Khotimah \& Cemerlang, 2014).

Data World Health Organization (WHO), Indonesia menempati urutan ke-4 terbesar dalam jumlah penderita diabetes melitus di dunia dan pada tahun 2000 lalu diperkirakan terdapat 4 juta penderita diabetes melitus di Indonesia. Jumlah ini diperkirakan akan terus meningkat. Pada tahun 2010 diperkirakan menjadi 5 juta dan tahun 2030 diperkirakan sekitar 21,3 juta penduduk Indonesia menderita diabetes melitus (Simanjuntak, 2016).

Berdasarkan Data Riset Kesehatan dasar tahun 2018 prevalensi diabetes melitus semua umur masih tinggi yaitu 1,5\%, sedangkan Gorontalo menempati tertinggi prevalensi 1,7 dengan posisi urutan ke 8 dari 33 provinsi lainnya di Indonesia. Berdasarkan Data Riset Kesehatan dasar tahun 2018, Provinsi Gorontalo prevalensi diabetes melitus pada semua umur yaitu 1,7\%. Sedangkan Kota Gorontalo menempati prevalensi tertinggi dengan proporsi 2,87\% dibandingkan dengan Kabupaten Gorontalo yaitu 1,88\%, Kabupaten Gorontalo Utara yaitu $1,73 \%$, Kabupaten Bone Bolango yaitu 1,33\%, dan Kabupaten Boalemo yaitu 0,73\%.

Diabetes melitus dapat dikendalikan dengan terapi non obat. Terapi non obat ini diantaranya menambah pengetahuan mengenai diabetes, rutin berolahraga, menjalankan pola makan yang tepat, serta mengonsumsi tanaman obat. Cara kerja tanaman obat dalam mengatasi diabetes yaitu dengan menghambat penyerapan gula darah sehingga jumlahnya di dalam tubuh tidak melebihi batas normal. Tanaman obat yang bekerja dengan cara ini diantaranya alpukat, buncis, jagung, jambu biji, lamtoro, kemlandingan, mahoni, dan salam. Tanaman jambu biji yang dapat dijadikan obat diabetes melitus adalah buah dan daunnya (Nur, 2017). Kandungan yang terdapat di dalam daun jambu biji yaitu tanin dan kalsium. Daun jambu biji adalah herbal yang bermanfaat sebagai penormal fungsi kelenjar pankreas dengan efek farmakologis memperlancar sistem sirkulasi darah dalam membantu menormalkan fungsi pankreas dalam mengatasi diabetes melitus (Maharani et al 2013).

Ada dua jenis jambu yaitu jambu air dan jambu biji. Berdasarkan pengamatan jenis jambu yang mudah ditemukan dikalangan masyarakat yaitu jambu biji. Kandungan kimia pada buah, daun, dan kulit batang pohon jambu biji adalah tanin. Tanin dapat menurunkan kadar glukosa darah. Hal ini sudah dibuktikan dengan penelitian yang dilakukan oleh (Maharani et al 2013), menjelaskan ada pengaruh pemberian air rebusan daun jambu biji terhadap kadar glukosa darah pada penderita diabetes melitus tipe II di Desa Leyangan Kecamatan Ungaran Timur Kabupaten Semarang. Terapi air rebusan daun jambu biji dapat digunakan sebagai 
alternatif untuk penatalaksanaan dalam menurunkan kadar glukosa darah pada penderita diabetes melitus tipe II. Penelitian sebelumnya memerlukan sebuah penelitian yang lebih lanjut, maka pentingnya penelitian lanjutan ini untuk memperoleh tingkat kepastian dalam penjabarannya.

Berdasarkan pengambilan data awal di Puskesmas Kota Selatan tahun 2018 diperoleh masyarakat yang menderita diabetes melitus sebanyak 775 penderita dengan kasus baru sebanyak 175 penderita dan kasus lama sebanyak 600 penderita. Adapun penanganan yang dilakukan di Puskesmas Kota Selatan untuk mengatasi penyakit diabetes melitus petugas Puskesmas Kota Selatan hanya memberikan obat antidiabetik, selain itu beberapa program terapi non obat untuk mengatasi terjadinya diabetes melitus di Puskesmas Kota Selatan yang sudah berjalan yaitu Prolanis dan Posbindu. Pada program ini kegiatan yang dilaksanakan adalah penyuluhan, pemeriksaan berkala dan senam.

Dari hasil wawancara dengan petugas di Puskesmas Kota Selatan penderita diabetes melitus di wilayah kerja Puskesmas Kota Selatan belum mengsosialisasikan atau mendemonstasikan tentang pengobatan diabetes melitus menggunakan obat tradisional. Begitu juga hasil wawancara dengan pasien diabetes melitus, pasien belum pernah mengkonsumsi obat tradisional untuk mengatasi penyakitnya.

Dari penjelasan diatas maka peneliti tertarik untuk melakukan penelitian tentang pengaruh pemberian air rebusan daun jambu biji terhadap kadar glukosa darah pada penderita diabetes melitus di Puskesmas Kota Selatan Kota Gorontalo.

\section{Metode}

Penelitian ini menggunakan jenis penelitian atau metode Pra-Expreriment yang bersifat One group pre-test dan post-test design. Dalam penelitian ini peneliti ingin menganalisis pengaruh pemberian air rebusan daun jambu biji terhadap penurunan kadar glukosa darah pada penderita diabetes melitus di Puskesmas Kota Selatan Kota Gorontalo.

Populasi dalam penelitian ini adalah semua penderita diabetes melitus di Puskesmas Kota Selatan Kota Gorontalo. Jumlah populasi dalam penelitian adalah jumlah kasus baru dan kasus lama pada bulan desember sejumlah 64 Penderita. Sampel yang akan diambil oleh peneliti berjumlah 37 orang. Teknik pengambilan sampel yang digunakan dalam penelitian ini yaitu menggunakan teknik purposive sampling yang mempunyai kriteria: bersedia menjadi responden, penderita diabetes melitus dengan kadar glukosa darah sewaktu $\geq 140 \mathrm{mg} / \mathrm{dL}$, penderita diabetes melitus dengan Kesadaran compos mentis. penderita diabetes melitus dengan usia $\geq 40$.

Instrumen penelitian yang digunakan peneliti adalah lembar obsevasi pemeriksaan kadar glukosa darah sebelum dan sesudah dilakukan eksperimen menggunakan alat pemeriksaan gula darah (NESCO), SOP pemeriksaan gula darah, SOP pemberian air rebusan daun jambu biji, dan lembar persetujuan menjadi Responden.

Teknik pengumpulan data menggunakan data primer yang diperoleh langsung dari data responden melalui lembar observasi yang digunakan oleh peneliti untuk mengukur kadar glukosa darah sebelum dan sesudah dilakukan pemberian air rebusan daun jambu biji yang 
dilakukan 2 kali sehari selama 7 hari. Sedangkan data skunder diperoleh dari beberapa dokumen yang diperoleh langsung dari data Dinas Kesehatan Kota Gorontalo, Puskesmas Kota Selatan Kota Gorontalo, serta literatur buku-buku yang berhubungan dengan penelitian serta pendukung lainnya. Analisa data menggunakan analisa unvariat dengan bivariat.

\section{Hasil}

Adapun hasil penelitian ini akan dideskripsikan melalui analisis univariat dan bivariat yang akan dijabarkan sebagai berikut :

1. Karakteristik Responden

Karakteristik responden dalam penelitian meliputi umur, jenis kelamin, pendidikan dan pekerjaan. Untuk lebih jelasnya akan diuraikan berikut ini :

a. Umur

Tabel 1. Distribusi Frekuensi Penggolongan Umur

\begin{tabular}{lcc}
\hline \multicolumn{1}{c}{ Umur } & Frekuensi & Presentase \\
\hline $35-44$ Tahun & 6 & 16,2 \\
\hline $45-54$ Tahun & 8 & 21,6 \\
\hline 55-64 Tahun & 18 & 48,6 \\
\hline $65-74$ Tahun & 5 & 13,5 \\
\hline Total & 37 & 100 \\
\hline
\end{tabular}

Sumber : Data Primer

Berdasarkan tabel, dapat dilihat bahwa jumlah responden terbanyak berada pada umur 55 - 64 Tahun yakni berjumlah 18 orang dengan presentase 48,6\%.

b. Jenis Kelamin

Tabel 2. Distribusi Frekuensi Penggolongan Jenis Kelamin

\begin{tabular}{lcc}
\hline \multicolumn{1}{c}{ Jenis Kelamin } & Frekuensi & Presentase \\
\hline Laki - Laki & 11 & 29,7 \\
\hline Perempuan & 26 & 70,3 \\
\hline Total & 37 & 100 \\
\hline
\end{tabular}

Sumber : Data Primer

Berdasarkan tabel, dapat dilihat bahwa jumlah responden terbanyak adalah berjenis kelamin perempuan sebanyak 26 orang $(70,3 \%)$ sedangkan responden berjenis kelamin laki-laki berjumlah lebih sedikit yaitu 11 orang $(29,7 \%)$.

c. Pendidikan

Tabel 3. Distribusi Frekuensi Penggolongan Pendidikan

\begin{tabular}{|c|c|c|}
\hline Pendidikan & Frekuensi & Presentase \\
\hline SD & 15 & 40.5 \\
\hline SMP & 10 & 27.0 \\
\hline SMA & 11 & 29.7 \\
\hline Perguruan Tinggi & 1 & 2.7 \\
\hline Total & 37 & 100 \\
\hline
\end{tabular}

Sumber : Data Primer 
Berdasarkan tabel, diketahui bahwa jumlah responden yang terbanyak yaitu berpendidikan SD berjumlah 15 orang (40,5\%).

d. Pekerjaan

Tabel 4. Distribusi Frekuensi Penggolongan Pekerjaan

\begin{tabular}{|c|c|c|}
\hline Pekerjaan & Frekuensi & Presentase \\
\hline Petani & 2 & 5.4 \\
\hline IRT & 20 & 54.1 \\
\hline Swasta & 10 & 27.0 \\
\hline Honorer & 1 & 2.7 \\
\hline Pensiunan & 3 & 8.1 \\
\hline Tidak bekerja & 1 & 2.7 \\
\hline Total & 37 & 100 \\
\hline
\end{tabular}

Sumber : Data Primer

Berdasarkan tabel, diketahui bahwa jumlah responden yang terbanyak yaitu dengan pekerjaan IRT berjumlah 20 orang $(54,1 \%)$.

e. Berat Badan

Tabel 5. Deskriptif Rerata Berdasarkan Berat Badan

\begin{tabular}{cccccc}
\hline Variabel & $\mathrm{n}$ & Rerata & $\mathrm{SD}$ & \multicolumn{2}{c}{$95 \%$ Confidence interval } \\
\cline { 5 - 6 } & & & & Lower & Upper \\
\hline Berat Badan $(\mathrm{kg})$ & 37 & 55,30 & 9,800 & 52,03 & 58,56 \\
\hline
\end{tabular}

Sumber : Data Primer

Berdasarkan tabel, dapat diketahui bahwa Rerata Berat Badan responden adalah $55,30 \mathrm{~kg}$ dengan Berat Badan tertinggi yaitu $75 \mathrm{~kg}$ dan Tinggi Badan terendah yaitu 35 $\mathrm{kg}$.

2. Analisa Univariat

a. Kadar Glukosa Darah Sebelum dan Sesudah Pemberian Air Rebusan Daun Jambu Biji

Tabel 6. Distribusi Pemeriksaan Glukosa Darah Sebelum dan Sesudah Pemberian Air

Rebusan Daun Jambu Biji

\begin{tabular}{cccccccc}
\hline $\begin{array}{c}\text { Kadar Glukosa } \\
\text { Darah }\end{array}$ & $\mathrm{N}$ & Mean & Median & Min & Max & $\begin{array}{c}\text { Standar } \\
\text { deviation }\end{array}$ & CI 95\% \\
\hline Pretest & 37 & 270.19 & 248.00 & 153 & 500 & 95.476 & $238.36-302.02$ \\
Posttest & 37 & 173.14 & 170.00 & 74 & 280 & 56.712 & $154.23-192.04$ \\
\hline
\end{tabular}

Sumber : Data Primer

Berdasarkan tabel, menunjukkan bahwa kadar glukosa darah sebelum dilakukan perlakuan pemberian air rebusan daun jambu rata-rata sebesar $270.19 \mathrm{mg} / \mathrm{dL}$ dengan median $248.00 \mathrm{mg} / \mathrm{dL}$, standar Deviasi 95.476, dengan CI 95\% Lower 238.36 dan Upper 302.02. Kadar glukosa darah terendah pada pretest didapatkan $153 \mathrm{mg} / \mathrm{dL}$ dan tertinggi $500 \mathrm{mg} / \mathrm{dL}$. Sedangkan untuk rata-rata kadar glukosa darah setelah diberikan perlakuan pemberian air rebusan daun jambu yaitu $173.14 \mathrm{mg} / \mathrm{dL}$ dengan median $170.00 \mathrm{mg} / \mathrm{dL}$, 
standar Deviasi 56.712, dan CI 95\% Lower 154.23 dan Upper 192.04. Kadar glukosa darah terendah pada posttest didapatkan $74 \mathrm{mg} / \mathrm{dL}$ dan tertinggi $280 \mathrm{mg} / \mathrm{dL}$.

b. Pengelompokan Kadar Glukosa Darah Sebelum dan Sesudah Pemberian Air Rebusan Daun Jambu Biji.

Tabel 7. Distribusi Pengelompokan Kadar Glukosa Darah Sebelum dan Sesudah Pemberian Air Rebusan Daun Jambu Biji

\begin{tabular}{ccccc}
\hline \multirow{2}{*}{ Kadar Glukosa Darah } & \multicolumn{2}{c}{ Pretest } & \multicolumn{2}{c}{ Posttest } \\
\cline { 2 - 5 } & $\mathrm{N}$ & $\%$ & $\mathrm{~N}$ & $\%$ \\
\hline Normal $<140 \mathrm{mg} / \mathrm{dL}$ & 0 & 0 & 15 & 40,5 \\
\hline Pradiabetes $140-200 \mathrm{mg} / \mathrm{dL}$ & 12 & 32,4 & 7 & 19 \\
\hline Diabetes $>200 \mathrm{mg} / \mathrm{dL}$ & 25 & 67,6 & 15 & 40,5 \\
\hline Jumlah & 37 & 100 & 37 & 100 \\
\hline
\end{tabular}

Sumber : Data Primer

Berdasarkan tabel tersebut, dari 37 orang responden, terdapat 21 orang yang mengalami penurunan kategori kadar glukosa darah setelah diberikan air rebusan daun jambu biji walaupun 16 orang mengalami penurunan kadar glukosa darah tetapi pada kategori yang tetap.

3. Analisa Data Bivariat

a. Uji Normalitas Data

Tabel 8. Uji Normalitas Data Kadar Glukosa Darah Sebelum dan Sesudah Pemberian Air Rebusan Daun Jambu Biji

\begin{tabular}{lrrr}
\hline & \multicolumn{3}{c}{ Shapiro - Wilk } \\
\cline { 2 - 4 } & Statistic & df & Sig. \\
\hline Pretest Kadar Glukosa Darah & .925 & 37 & $.016^{*}$ \\
\hline Posttest Kadar Glukosa Darah & .935 & 37 & $.032^{*}$ \\
\hline *Normalitas Data Shapiro - Wilk $<\alpha(0,05)$
\end{tabular}

Pada tabel, sebelum dilakukan analisis uji korelasi terhadap pengaruh pemberian air rebusan daun jambu biji (psidium guajava) terhadap kadar glukosa darah pada penderita diabetes melitus di Puskesmas Kota Selatan Kota Gorontalo terlebih dahulu data glukosa darah sebelum dan sesudah diuji analisis normalitas data. Pada penelitian ini peneliti menggunakan analisis normalitas menggunakan uji Shapiro-Wilk dikarenakan jumlah sampel $<50$. Berdasarkan tabel tersebut dapat diketahui bahwa nilai $\rho$ untuk, glukosa darah sebelum dan sesudah, $<\alpha(0,05)$ maka dapat diinterpretasikan bahwa data tidak terdistribusi dengan normal. Sehingga uji yang digunakan menggunakan uji Wilcoxon.

b. Analisis Pengaruh Pemberian Air Rebusan Daun Jambu Biji (Psidium Guajava) terhadap Kadar Glukosa Darah pada Penderita Diabetes Melitus Di Puskesmas Kota Selatan Kota Gorontalo 
Tabel 9. Analisis Pengaruh Pemberian Air Rebusan Daun Jambu Biji (Psidium Guajava) terhadap Kadar Glukosa Darah pada Penderita Diabetes Melitus

\begin{tabular}{ccccc}
$\begin{array}{c}\text { Kadar Glukosa } \\
\text { Darah }\end{array}$ & $n$ & Mean & $\begin{array}{c}\text { Median } \\
\text { (Min-Max })\end{array}$ & $\rho$-value \\
\cline { 1 - 4 } Pretest & 37 & 270.19 & $248.00(153-500)$ & \multirow{2}{*}{0,000} \\
\hline Postest & 37 & 173.14 & $170.00(74-280)$ &
\end{tabular}

Berdasarkan analisis pada tabel, menunjukkan hasil uji statistik dengan menggunakan uji wilcoxon bahwa sebelum diberikan air rebusan daun jambu biji didapatkan nilai median $248.00 \mathrm{mg} / \mathrm{dL}$ (Diabetes). Kadar glukosa darah terendah sebelum diberikan air rebusan daun jambu biji yaitu $153 \mathrm{mg} / \mathrm{dL}$ (Pradiabetes) dan kadar glukosa darah tertinggi sebelum diberikan air rebusan daun jambu biji yaitu $500 \mathrm{mg} / \mathrm{dL}$ (Diabetes), sedangkan kadar glukosa darah setelah diberikan air rebusan daun jambu biji memiliki nilai median $170.00 \mathrm{mg} / \mathrm{dL}$ (Pradiabetes) dengan kadar glukosa darah terendah yaitu $74 \mathrm{mg} / \mathrm{dL}$ (Normal) dan kadar glukosa darah tertinggi yaitu $280 \mathrm{mg} / \mathrm{dL}$ (Diabetes) dengan $\rho$-value 0.000. Analisis Uji Wilcoxon didapatkan nilai $\rho=0,000$ pada kadar glukosa darah sebelum dan sesudah diberikan air rebusan daun jambu biji. Dengan hipotesis penelitian $\rho<\alpha(0.000<0.05)$, yang artinya kadar glukosa darah menunjukkan kurang dari nilai $\alpha 0.05$ dengan maka dapat diartikan bahwa hipotesis Ha pada penelitian ini diterima (Ho ditolak) yang artinya ada penurunan kadar glukosa sebelum dan sesudah diberikan air rebusan daun jambu biji di Wilayah Puskesmas Kota Selatan Kota Gorontalo.

\section{Pembahasan}

1. Karakteristik Responden

a. Umur

Hasil penelitian menunjukan bahwa penuaan mempengaruhi perubahan hormone yang mengatur metabolism, fungsi reproduksi serta dapat mempengaruhi kepekaan sel beta pancreas terhadap gula darah dan menunda penyerapan gula darah oleh insulin.

Sejalan dengan penelitian menunjukkan bahwa kelompok usia 48-64 tahun mempunyai resiko mengalami DM tiga kali lebih tinggi dibandingkan dengan usia 25-40 tahun (Betteng, 2014). Hal tersebut dikarenakan peningkatan intoleransi glukosa yaitu kemampuan sel beta pancreas dalam memproduksi insulin berkurang karena adanya proses penuaan. Selain itu adanya penurunan aktivitas fisik serta pola makan yang tidak terkontrol menyebabkan sulitnya mengendalikan glukosa darah pada pasien DM (Nurayati \& Adriani, 2017), hal ini disebabkan karena adanya penurunan sistem fisiologis dan kimiawi, dimana perubahan dimulai dari tingkat sel kemudian berlanjut ke tingkat jaringan dan pada akhirnya ketingkat organ yang dapat mempengaruhi homeostatis (Damayati et al., 2018). 
b. Jenis Kelamin

Hasil penelitian menunjukkan bahwa kejadian penyakit DM umumnya terjadi pada perempuan karena secara fisik perempuan memiliki peluang mengalami peningkatan berat badan yang lebih besar. Fluktuasi kadar hormon estrogen yang dimiliki perempuan akan meingkat lalu mempengaruhi tubuh menjadi resistensi terhadap insulin kemudian setelah menopause distribusi lemak tubuh menjadi mudah terakumulasi akibat proses hormonal tersebut sehingga perempuan lebih beresiko mengalami DM (KautzkyWiller et al., 2016).

c. Pendidikan

Hasil penelitian menunjukan bahwa tingkat pengetahuan rendah akan sulit menerima informasi yang disampaikan sedangkan apabila tingkat pendidikan tinggi akan lebih mudah menerima informasi yang disampaikan berdasarkan pengalaman dan budaya yang ada pada masyarakat tertentu (Azis et al., 2020)(Kusnanto et al., 2019).

d. Pekerjaan

Hasil penelitian menunjukan bahwa jenis pekerjaan biasanya berhubungan dengan aktifitas fisik dan aktifitas olahraga. Ibu rumah tangga (IRT) melakukan beberapa aktifitas fisik di rumah seperti mencuci, memasak, dan membersihkan rumah serta banyak aktifitas fisik lainnya yang tidak dapat dideskripsikan. Aktifitas fisik akan berpengaruh terhadap peningkatan insulin sehingga kadar gula dalam darah akan berkurang. Jika insulin tidak mencukupi untuk mengubah glukosa menjadi energi maka akan timbul DM. Pekerjaan sebagai ibu rumah tangga termasuk dalam aktifitas ringan, dimana orang yang aktifitasnya ringan memiliki resiko 4,36 kali lebih besar untuk mederita DM tipe II dibandingkan dengan orang yang memiliki aktifitas sedang dan berat (Sukardji, 2013).

e. Berat Badan

Hasil penelitian menunjukan bahwa berat badan seseorang dapat mempengaruhi kadar glukosa dalam darah seseorang dengan berat badan berlebih atau obesitas atau kegemukan menyebabkan tubuh seseorang mengalami resistensi terhadap hormone insulin (Masrul, 2018). Akibatnya organ pankreas akan dipacu untuk memproduksi insulin sebanyak-banyaknya sehingga menjadikan organ ini menjadi kelelahan dan akhirnya rusak (Haris \& Tambunan, 2016).

2. Analisa Univariat

a. Kadar Glukosa Darah Sebelum dan Sesudah Pemberian Air Rebusan Daun Jambu Biji

Hasil penelitian ini menunjukkan terjadi penurunan rerata kadar glukosa darah sebelum dan sesudah diberikan air rebusan daun jambu biji. Penurunan ini disebabkan karena kandungan yang terdapat didalam daun jambu biji yaitu tanim dan kalsium (Sutrisno \& Hidayat, 2018). Tanim adalah zat pahit polifenol yang sangat baik dan cepat mengikat protein. Daun jambu biji (Psidium Guajava) adalah herbal yang bermanfaat sebagai penormal fungsi kelenjar pancreas dengan efek farmakologis memperlancar 
sistem sirkulasi darah dalam membantu menormalkan fungsi pancreas dalam mengatasi diabetes mellitus.

b. Pengelompokan Kadar Glukosa Darah Sebelum dan Sesudah Pemberian Air Rebusan Daun Jambu Biji.

Hasil penelitian menunjukkan bahwa dari 37 orang responden, terdapat 21 orang yang mengalami penurunan kategori kadar glukosa darah setelah diberikan air rebusan daun jambu biji walaupun 16 orang mengalami penurunan kadar glukosa darah tetapi pada kategori yang tetap. Dimana dari kategori Diabetes - Diabetes sebanyak 15 orang, Diabetes - Pradiabetes sebanyak 6 orang, Diabetes - Normal sebanyak 4 orang, Pradiabetes - Pradiabetes 1 orang, dan Pradiabetes - Normal sebanyak 11 orang.

3. Analisa Bivariat

Setelah diberikan terapi air rebusan daun jambu biji (Psidium guajava) selama 7 hari, responden mengalami penurunan kadar glukosa darah, dan ada perbedaan kadar glukosa darah antara sebelum dan sesudah pemberian air rebusan daun jambu biji pada penderita diabetes melitus di Wilayah Kerja Puskesmas Kota Selatan Kota Goronalo.

Hasil penelitian ini sejalan dengan penelitian (Maharani et al 2013) yang menyatakan bahwa ada perbedaan yang signifikan kadar glukosa darah puasa pada kelompok intervensi sebelum dan setelah diberikan terapi air rebusan daun jambu biji pada penderita diabetes melitus tipe II di Desa Leyangan Kec. Ungaran Timur Kab. Semarang. Dapat dilihat dari hasil p-value $0,000<\alpha(0,005)$, sedangakan pada kelompok kontrol dinyatakan bahwa tidak ada perbedaan yang signifikan kadar glukosa darah puasa pada kelompok kontrol sebelum dan setelah diberikan terapi air rebusan daun pandan pada penderita diabetes mellitus tipe II di Desa Leyangan Kec. Ungaran Timur Kab. Semarang. Dapat dilihat dari hasil p-value $0,703>\alpha(0,005)$.

Penelitian selanjutnya yang dilakukan oleh (Hani, 2018) berdasarkan hasil uji statistik dengan menggunakan uji Mc. Nemar maka didapatkan nilai signifikasi 0,031 yang berarti lebih kecil dari $\alpha=0,05$ yang berarti bahwa ada perbedaan yang bermakna antara glukosa darah sebelum pemberian air rebusan daun jambu biji 10 lembar dan setelah pemberian air rebusan daun jambu biji maka dengan ini hipotesis Ho ditolak dan hipotesis Ha di terima yang berarti ada pengaruh pemberian air rebusan daun jambu biji terhadap penurunan kadar glukosa darah pada penderita diabetes melitus tipe II di Puskesmas Pekkabata Kabupaten Polewali Mandar.

\section{Kesimpulan}

Sebelum diberikan air rebusan daun jambu biji di Wilayah Kerja Puskesmas Kota Selatan dilakukan pengukuran glukosa darah dan didapatkan mengalami glukosa darah tinggi. Penderita diabetes melitus yang memiliki kadar glukosa darah tinggi di Wilayah Kerja Puskesmas Kota Selatan setelah diberikan air rebusan daun jambu biji semua mengalami penurunan glukosa darah. Ada pengaruh yang sangat signifikan antara air rebusan daun jambu biji dan penurunan kadar glukosa darah pada penderita diabetes melitus di Wilayah Kerja 
Puskesmas Kota Selatan.

\section{Referensi}

Azis, W. A., Muriman, L. Y., \& Burhan, S. R. (2020). Hubungan Tingkat Pengetahuan dengan Gaya Hidup Penderita Diabetes Mellitus. Jurnal Penelitian Perawat Profesional. https://doi.org/10.37287/jppp.v2i1.52

Betteng, R. (2014). Analisis Faktor Resiko Penyebab Terjadinya Diabetes Melitus Tipe 2 Pada Wanita Usia Produktif Dipuskesmas Wawonasa. Jurnal E-Biomedik. https://doi.org/10.35790/ebm.2.2.2014.4554

Damayati, R. P., Roosita, K., \& Sulaeman, A. (2018). Effect of Galohgor Cookies and Powder Drinks on Visceral Adipose Tissue and Lipid Profile in Patients with Type 2 Diabetes Mellitus. Jurnal Gizi Dan Pangan. https://doi.org/10.25182/jgp.2018.13.3.137-144

Hani, U. (2018). Pengaruh Pemberian Air Rebusan Daun Jambu Biji Terhadap Kadar Glukosa Darah Pada Penderita Diabetes Mellitus Tipe Ii Di Wilayah Kerja Puskesmas Pekkabatakabupaten Polewali Mandar. Bina Generasi: Jurnal Kesehatan. https://doi.org/10.35907/jksbg.v9i2.40

Haris, S., \& Tambunan, T. (2016). Hipertensi pada Sindrom Metabolik. Sari Pediatri. https://doi.org/10.14238/sp11.4.2009.257-63

Kautzky-Willer, A., Harreiter, J., \& Pacini, G. (2016). Sex and gender differences in risk, pathophysiology and complications of type 2 diabetes mellitus. In Endocrine Reviews. https://doi.org/10.1210/er.2015-1137

Kementerian Kesehatan Republik Indonesia. (2020). Infodatin Diabetes Melitus. Pusat Data Dan Informasi Kementrian Kesehatan RI.

Khotimah, K., \& Cemerlang, T. R. (2014). Sehat dan Lezat Menu untuk Penderita Diabetes Melitus (1st ed.). Rapha Publishing.

Kusnanto, K., Sundari, P. M., Asmoro, C. P., \& Arifin, H. (2019). Hubungan Tingkat Pengetahuan Dan Diabetes Self-Management Dengan Tingkat Stres Pasien Diabetes Melitus Yang Menjalani Diet. Jurnal Keperawatan Indonesia. https://doi.org/10.7454/jki.v22i1.780

Maharani, Rosalina, dan Puwaningsih, P. (2013). Pengaruh Pemberian Air Rebusan Daun Jambu Biji (Psidium Guajava) Terhadap Kadar Glukosa Darah Pada Penderita Diabetes Melitus Tipe II. Jurnal Keperawatan Medikal.

Masrul, M. (2018). Epidemi obesitas dan dampaknya terhadap status kesehatan masyarakat serta sosial ekonomi bangsa. Majalah Kedokteran Andalas. https://doi.org/10.25077/mka.v41.i3.p152-162.2018

Nurayati, L., \& Adriani, M. (2017). Hubungan Aktifitas Fisik dengan Kadar Gula Darah Puasa Penderita Diabetes Melitus Tipe 2. Amerta Nutrition. https://doi.org/10.20473/amnt.v1i2.6229

Simanjuntak, H. A. (2016). Etnobotani Tumbuhan Obat Di Masyarakat Etnis Simalungun Kabupaten Simalungun Provinsi Sumatera Utara. BIOLINK (Jurnal Biologi Lingkungan, Industri, Kesehatan).

Sukardji, K. (2013). Pentalaksanaan Gizi pada Diabetes Melitus. In Penatalaksanaan Diabetes Melitus Terpadu.

Sutrisno, S., \& Hidayat, D. P. (2018). Efektivitas Penggunaan Daun Jambu Biji (Psidium Guajava) Dan Daun Sirih Merah (Piper Crocatum) Terhadap Pengontrolan Odour (Bau) Pada Pasien Dengan Luka Diabetes Mellitus Di Fatchul Wound Care. The Shine Cahaya Dunia Ners. https://doi.org/10.35720/tscners.v3i1.57

Syamsiyah Nur. (2017). Berdamai Dengan Diabetes. In Bumi Medika. 